\title{
Ecological Destruction in Indonesia: Reflecting on the Experience of East Kalimantan and Bangka Belitung
}

\author{
Hendra Try Ardianto ${ }^{1}$, Laila Kholid Alfirdaus ${ }^{2}$, S. Rouli Manalu ${ }^{3}$, Kushandajani ${ }^{4}$ \\ \{hendratrya@gmail.com ${ }^{1}$ \} \\ Universitas Diponegoro, Indonesia ${ }^{1,2,3,4}$
}

\begin{abstract}
This article shows an overview of how ecological destruction occurs in Indonesia, especially in two regions, that is East Kalimantan and Bangka Belitung. Both regions are rich in natural resources, but due to over-exploitation, thus impacting ecological destruction. To get this description, the writer conducted a qualitative study by interviewing dozens of cross-sectoral informants in the two regions in mid-JulySeptember 2019. The results showed that there were thousands of ex-mining holes left by the company, and has caused many people to die there. By borrowing the perspective of ecological destruction from Bellamy Foster (2007), the authors find the fact that excessive and uncontrolled exploitation of the natural resource in East Kalimantan and Bangka Belitung, has destroyed the ecological carrying capacity of the environment, as well as the life force of people who live in it. This condition will continue to occur if the rate of capital accumulation that exploits excessive natural resources is not stopped.
\end{abstract}

Keywords: Mining, Exploitation of Natural Resources, Ecological Destruction.

\section{Introduction}

This paper aims to find out how ecological destruction occurs in areas that have a status as regions rich in natural resources? In order to get this answer, this article will take East Kalimantan and Bangka Belitung as the focus of the study to be compared. East Kalimantan Province (after this referred to as East Kalimantan) is an area rich in coal mines. While the Bangka Belitung Islands Province (after this referred to as Babel) has long been widely known as a tin-producing region. Both of these regions have a long political history of mining.

East Kalimantan is the largest coal-producing region in Indonesia, with a production capacity of around $60 \%$ of national production EITI [1]. According to the latest BPS data, until the end of 2018, coal production in East Kalimantan reaches around 250 million tons. When combined with oil and gas, the mining sector accounts for $46.35 \%$ of the GRDP (Gross Regional Domestic Product) of East Kalimantan [2]. That means, almost half the economy of East Kalimantan depends on the survival of the mining sector.

Whereas Babel is an area that has the largest tin reserves in Indonesia. According to the latest BPS data, in $2018 \mathrm{Babel}$ is capable of producing more than 70 thousand tons of tin ore. Of this production, almost all of it was used for export purposes, which in 2018 recorded an export value of 1,361.1 thousand US dollars [3]. As for the mining sector itself, it has a contribution of $10.50 \%$ of the GRDP on Bangka Island, and $11.31 \%$ of the Belitung Island GRDP [4]. These numbers show that the level of dependence on the mining sector in Bangka Belitung is lower than in East Kalimantan. 
As for looking at ecological destruction in East Kalimantan and Bangka Belitung, the authors used a descriptive qualitative methodology with desk study and field research conducted in mid-July-September 2019. In the field research, the authors did interviews and Forum Group Discussions (FGD) with various parties, such as entrepreneurs, government officials, non-government organizations (NGOs), academics, and communities directly affected by mining.

In this article, the author uses the ecological destruction framework used by John Bellamy Foster. The existence of ecological destruction is a result of the pursuit of uncontrolled profits, carried out by taking over and dominating resources, which ultimately have an impact on destroy to production and even living conditions themselves [5]. In the view of Foster Foster [5], ecological destruction cannot be released from a capitalistic economic perspective. According to him, excessive capital accumulation will create a metabolic rift between humans and nature, which break the necessary process of natural reproduction. This condition is what will later destroy the productive economic on society, and simultaneously also eliminate the ability of nature to renew itself.

\section{Result and Discussion}

\subsection{Exploitation of Natural Resources: Between Benefits and Losses}

There are always pros and cons in seeing the exploitation of natural resources, especially related to the dichotomy of economic benefits and ecological destruction [6]. One side, exploiting natural resources has many benefits because the results can be used as a driver of development. With the exploitation of resources, especially by large-scale companies, there will be open employment, infrastructure development, increase state revenues, increase investment, and to the existence of compensation schemes from companies [7]. Moreover, with good governance, mining products are believed to be used poverty reduction $[8][9][10][11]$.

On the other hand, mining can also destroy the environment on a scale that is difficult to repair. A concrete example of this is the "ghost town" phenomenon due to mining activities. In 2000, copper mining in Zimbabwe experienced a drastic decline that caused cities such as Shackleton, Sutton, Vanad and Kildonan to become "ghost towns" [12]. This kind of phenomenon also occurs in developed countries. Some cities in America, such as Colorado, have many "ghost towns" due to a mining economy that has stopped [13]. On a smaller scale, as is the case in India, coal mining activities have degraded the habitat and landscape of biodiversity there [14].

Not only results in ecological destruction, development driven by the exploitation of natural resources, for some people labelled as a curse. This argument is based on the paradox of economic growth from the exploitation of natural resources (minerals) which is much slower compared to countries that rely on the economy from the non-mineral sector. This happens because: the value of raw minerals is vulnerable on the global market, the mismanagement of natural resources, including the tendency of rampant corruption in this sector [15][16]. Furthermore, in developed countries like America, Australia, Canada, mining also only contributes very little to national income. If there is economic development at the local level, it is generally not the impact of mining, even for some people the opinion that mining is often accompanied by poverty [17]. Not to mention the impact of conflict due to 
mining, as happened extremely in conflict diamonds in Angola, Sierra Leone and Congo [18] [19].

As for the case of Indonesia, ecological destruction due to mining activities is also not new. The most famous case is the mud overflow disaster which drowned dozens of villages due to mining engineering mistakes made by PT. Lapindo Brantas [20][21]. Another case is the destruction of the ecology of the Buyat Bay area due to the disposal of around 2000-5000 cubic tons of waste every day by PT. Newmont Minahasa Raya to the waters of Buyat Bay [22]. Cases of this type include: millions of deforested forests, mountains lost due to mining, and polluted rivers can be found scattered in various regions in Indonesia [23][24][25].

\subsection{What is the destruction like?}

As a region rich in natural resources, East Kalimantan presents itself as one of the most chaotic provinces in terms of the management of natural resource exploitation permits. Laode M. Syarif, Deputy Chairperson of the Corruption Eradication Commission (KPK) said that the East Kalimantan case was the only one in the world. How not, the area of land use permits for exploitation of natural resources reaches an area of 13.83 million hectares, even though the total land area of East Kalimantan province is only 12.7 hectares [26]. Of the 12.7 hectares of land area, 7.2 million hectares or $70 \%$ of the land has been cleared in the mining exploitation plan [27]. Excessive and overlapping permits in the exploitation of these resources have led to the emergence of numerous mining holes in the province.

One of the areas that are very striking about the existence of a large number of scattered mining pits is Samarinda City. A simple way to find out this fact is to look at it from the air just before the plane landed at Aji Pangeran Tumenggung Pranoto International Airport in Samarinda. Because of the large number of coal mining there, in the writer's observation when conducting field research, small-scale mining was also carried out in the vicinity of residntial housing and near government offices, such as behind the Samarinda Bawaslu office. The latest data submitted by Jatam, until the end of 2018 the number of holes former coal mines reached 1,735 points spread throughout East Kalimantan, although the East Kalimantan Government only recognizes as many as 500 holes [28].

The conditions above are not much different from the Province of Babel, the number of "underneath" -other languages from the former tin mining pits "was recorded very much. In the "Workshop on Control of Land Damage" on 12 September 2019, the Babylonian Watershed Forum delivered the following information.

\begin{tabular}{lcccc}
\multicolumn{5}{c}{ Table 1. Number and Spread of "Kolong" (ex-mine pit) the Bangka in Belitung } \\
\hline \multicolumn{1}{c}{ District } & $\begin{array}{c}\text { District Large } \\
(\mathrm{Ha})\end{array}$ & $\begin{array}{c}\text { Number of } \\
\text { ex-mine pit }\end{array}$ & $\begin{array}{c}\text { Large of ex-mine } \\
\text { pit (Ha) }\end{array}$ & $\begin{array}{c}\text { Ex-mine pit compared } \\
\text { to the district area }(\%)\end{array}$ \\
\hline Bangka Barat & 282.061 & 4.177 & 1.943 & $0,6 \%$ \\
Bangka & 295.069 & 3.665 & 2.676 & $0,9 \%$ \\
Bangka Tengah & 212.636 & 1.681 & 2.695 & $1,2 \%$ \\
Bangka Selatan & 360.708 & 710 & 730 & $0,2 \%$ \\
Pangkalpinang & 11.880 & 63 & 123 & $0,1 \%$ \\
Belitung & 229.369 & 1.166 & 2.200 & $0,9 \%$ \\
Belitung Timur & 250.700 & 1.432 & 5.164 & $2 \%$ \\
Total & $1.642 .423 \mathrm{Ha}$ & 12.894 & $15.532 \mathrm{Ha}$ & - \\
\hline
\end{tabular}

Source: BP DAS Bangka Belitung, 2018. 
From the table I above, it can be seen that the number of pits in all of Babel has reached 12,894 points and reaches an area of around 15,531.95 $\mathrm{Ha}$. The number and extent of these tin mining pits exacerbated the ecological conditions in Bangka Belitung, bearing in mind that mining practices, especially illegal ones, continued until this writing.

In addition to a large number of pits on the mainland of the Babel Islands, the exploitation of tin, especially for illegal mines, has claimed quite a lot of lives. Although there is no official data that is documented, observations in the mass media that the authors did show that only in the middle of July-August 2019, illegal tin mines had claimed the lives of around 19 people [29]. Cases of illegal tin workers who are buried by such landslides are news that often appears in local media in Babel every year [30].

In contrast, in the case of East Kalimantan, the ex-coal mining pit has killed 35 children from 2011-2019. This large number of casualties occurs because the location of the mine pit is usually not fenced and close enough to residential areas so that it is often used as a playground by children. This can be seen in the table below.

Table 2. List of the Children Victims at Ex-Mining Pit Cases in East Kalimantan from 2011 - 2019

\begin{tabular}{cc}
\hline District & Number of cases \\
\hline Samarinda & 21 cases \\
Kutai Kertanegara & 12 cases \\
Penajam Paser Utara & 1 case \\
Kutai Barat & 1 case \\
\hline Source: Processed from Internal Data of Jatam 2019 (not yet published).
\end{tabular}

Many incidents of children who drowned in the former mining pit were a result of the negligence of mining companies that did not carry out reclamation and post-mining obligations. Quite a lot of companies do not adjust their obligations; even some of them have not been able to trace their existence.

An ironic story about the unfortunate life in the midst of mining exploitation occurred in the two villages, namely Mulawarman Village, in Kutai Kertanegara District, East Kalimantan, and Mayang Village, in West Bangka District, Babel. Both of these villages are classified as villages where people suffer from mining expansion. Both villages have a relatively good agricultural history in the past. Mulawarman Village was once known as an abundant producer of rice, but now its position is surrounded by coal mining exploitation from all directions. In contrast, Mayang Village has a population of mostly farmers, especially for pepper and rubber. However, the situation is now changing because most of the community's work has shifted to mining in the early 2.000. Actually, they want to return to agriculture, but the environment that supports agriculture has been destroyed by the exploitation of tin mining that occurs evenly throughout the village. Regretful of being a miner, the writer found almost every informant from the village of Mayang.

Mulawarman Village is a unique village because there is not a single part of its territory that does not coincide with the coal mining area. Infield observations to this village, it was seen that the main road leading to the village had to go through a coal mining area which was also used as a road for large-sized dump trucks back and forth. According to local residents, the location of the road to the mine has been changed several times because it has to adjust the needs of the road used by the mining company.

Because the land around the village of Mulawarman was used for coal mining exploitation, some of the residents' wells experienced shrinkage and even lost their water. In the past few years, residents in this village have relied on water needs with four models. First, rainwater is collected, flowed, and contained in reservoirs. Second, buy water from residents 
who have wells with sufficient water reserves. Third, some hamlet receive water subsidies from companies in the amount of 1000 litres every two weeks. Fourth, use stagnant water in a former mine pit which is usually found around the edge of the village. As for the fourth point, it is still unclear the level of safety of the water used, whether it is safe to consume or not. An informant who is an official of Mulawarman Village said, "What can I do because it is indeed difficult and expensive to obtain clean water, many residents use water from the mine pits for their daily needs".

Picture 1. Tin Ex-Minning in Mayang Village, West Bangka

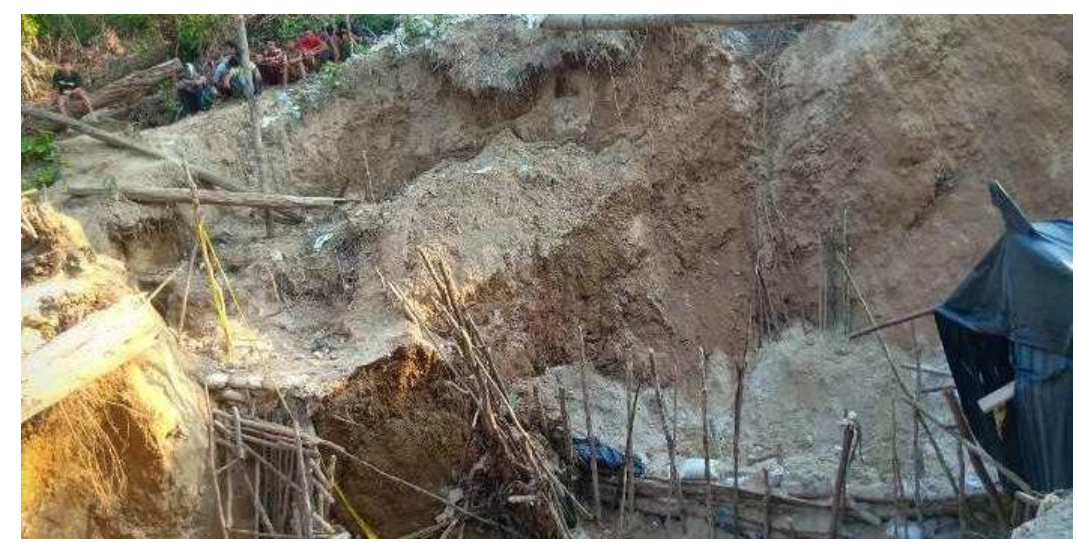

Source: Tribunnews [31].

Picture 2. Coal Ex-Minning in Mulawarman Village, Kutai Kertanegara

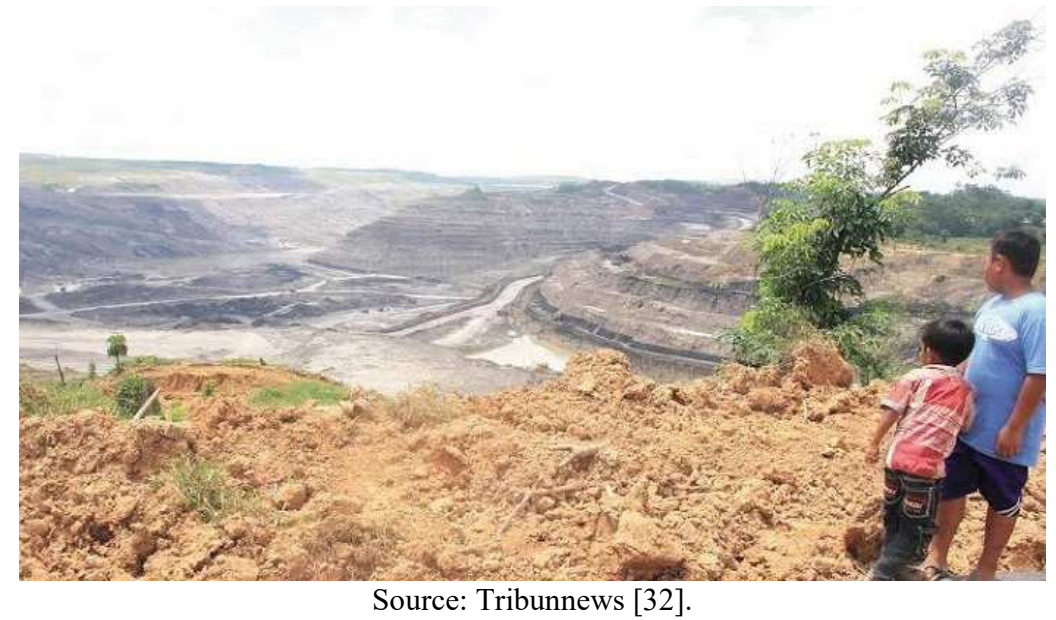

\section{Conclusion}

As an area that depends on mining economics sector, East Kalimantan and Bangka Belitung have left problems in the form of ecological destruction. This problem has not only 
affected the carrying capacity of the environment itself but has disrupted the life capacity of the people who live in it. Ecological destruction occurs because the government issues too many permits for excessive exploitation and does not consider the impact on the surrounding environment. This condition cannot be immediately corrected without stopping the upstream problem in the form of cessation of exploitation that continues to occur, both legal and illegal mining. As Foster (2007) narrated, the root of ecological destruction is the excessive accumulation of capital, which in turn creates a metabolic rift between natural and human relations until both are affected simultaneously.

However, the limitations of writing space are only enough to show how ecological destruction occur in these areas. This article has not yet highlighted the political and economic situation, such as what causes overexploitation to occur. In addition, this article has not yet examined the study of the extent of government solutions in overcoming the problem of ecological damage. Some of these issues require specific studies.

\section{References}

[1] EITI, "Factsheet Kalimantan Timur. Extractive Industries Transparency Initiative (EITI) Indonesia,” 2014. [Online]. Available: https://eiti.ekon.go.id/factsheet-kalimantantimur/?aid=1789\&sa $=1$.

[2] BPS, "Statistik Daerah Provinsi Kalimantan Timur 2019," Badan Pusat Statistik Kalimantan Timur. [Online]. Available: https://kaltim.bps.go.id/publication/2019/09/26/546053071e34675e 08a360ea/statistik-daerah-provinsi-kalimantan-timur-2019.html.

[3] BPS, "Statistik Daerah Provinsi Bangka Belitung 2019," Badan Pusat Statistik Bangka Belitung. [Online]. Available: https://babel.bps.go.id/publication/2019/09/26/16265afad6d7fbbc 58e94bc4/statistik-daerah-provinsi-kepulauan-bangka-belitung-2019.html.

[4] BPS, "Produk Domestik Regional Bruto Kabupaten/Kota di Provinsi Kepulauan Bangka Belitung Menurut Lapangan Usaha 2014-2018," Badan Pusat Statistik Bangka Belitung. [Online]. Available: https://babel.bps.go.id/publication/2019/07/05/9de837760c349a4c4a7b75 9a/produk-domestik-regional-bruto-provinsi-kepulauan-bangka-belitung-menurut-lapanganusaha-2014-2018.html.

[5] J. B. Foster, "The ecology of destruction," Mon. Rev., vol. 58, no. 9, p. 1, 2007.

[6] I. P. Singawinata, "The Future of the Indonesian Mining Industry: Recommendations to Policy Makers," Ritsumeikan J. Asia Pacific Stud., vol. 22, pp. 99-113, 2007.

[7] E. Wall and R. Pelon, "Sharing mining benefits in developing countries," 2011.

[8] E. Fisher, R. Mwaipopo, W. Mutagwaba, D. Nyange, and G. Yaron, “"The ladder that sends us to wealth': Artisanal mining and poverty reduction in Tanzania," Resour. Policy, vol. 34, no. 12, pp. 32-38, 2009.

[9] A. M. A. Pedro, "Mainstreaming mineral wealth in growth and poverty reduction strategies," Miner. Energy-Raw Mater. Rep., vol. 21, no. 1, pp. 2-16, 2006.

[10] S. Pegg, "Mining and poverty reduction: Transforming rhetoric into reality," J. Clean. Prod., vol. 14, no. 3-4, pp. 376-387, 2006.

[11] W. Bank, "Striking A Better Balance-The World Bank Group and Extractive Industries: The Final Report of the Extractive Industries Review." The World Bank Washington, DC, 2003.

[12] A. Y. Kamete, "Of prosperity, ghost towns and havens: mining and urbanisation in Zimbabwe," J. Contemp. African Stud., vol. 30, no. 4, pp. 589-609, 2012.

[13] P. E. Graves, S. Weiler, and E. E. Tynon, "The economics of ghost towns," J. Reg. Anal. Policy, vol. 39, no. 2, pp. 131-140, 2009.

[14] K. Sarma and S. K. Barik, "Coal mining impact on vegetation of the Nokrek Biosphere Reserve, Meghalaya, India," Biodiversity, vol. 12, no. 3, pp. 154-164, 2011.

[15] R. M. Auty, "Natural resources, capital accumulation and the resource curse," Ecol. Econ., vol. 
61, no. 4, pp. 627-634, 2007.

[16] J. D. Sachs and A. M. Warner, "The curse of natural resources," Eur. Econ. Rev., vol. 45, no. 46, pp. 827-838, 2001

[17] T. M. Power, "Digging to development? A historical look at mining and economic development," Oxfam Am. Rep., 2002.

[18] P. Le Billon, "Diamond wars? Conflict diamonds and geographies of resource wars," Ann. Assoc. Am. Geogr., vol. 98, no. 2, pp. 345-372, 2008.

[19] R. Maconachie and T. Binns, "Beyond the resource curse? Diamond mining, development and post-conflict reconstruction in Sierra Leone," Resour. Policy, vol. 32, no. 3, pp. 104-115, 2007.

[20] P. W. Batubara, B., \& Utomo, Kronik lumpur Lapindo: Skandal bencana industri pengeboran migas di Sidoarjo. INSISTPress., 2012.

[21] R. Gustomy, "Menjinakkan Negara, Menundukkan Masyarakat: Menelusuri Jejak Strategi Kuasa PT Lapindo Brantas Inc," Bencana Ind. dan Masy. sipil dalam penanganan lumpur Lapindo, pp. 31-98, 2010.

[22] K. Lutfillah, "Kasus Newmont (Pencemaran Di Teluk Buyat)," KYBERNAN J. Ilm. Ilmu Pemerintah., vol. 2, no. 1, pp. 17-29, 2011.

[23] G. J. Aditjondro, Kebohongan-kebohongan negara: perihal kondisi obyektif lingkungan hidup di Nusantara. Yogyakarta: Pustaka Pelajar., 2003.

[24] G. J. Aditjondro, Korban-korban pembangunan: tilikan terhadap beberapa kasus perusakan lingkungan di tanah air. Yogyakarta .: Pustaka Pelajar, 2003.

[25] C. Muhammad, S. Maimunah, and A. Kirom, "Tambang dan Kemiskinan: Catatan Kecil Kasus Pertambangan di Indonesia 2001-2003 [Mines and Poverty: Notes on Mining Cases in Indonesia 2001-2003]," Jakarta Jar. Advokasi Tambang, 2005.

[26] F. Nathaniel, "KPK: Izin Lahan di Kaltim Lebih Luas dari Daratan, Negara Apa Ini?," 2019. [Online]. Available: https://tirto.id/eepo.

[27] K. HAM, Pelanggaran Hak Asasi Manusia dalam Kasus Eks-Lubang Tambang Batubara di Kalimantan Timur. Jakarta: Komanas HAM, 2016.

[28] A. Utama, "Ibu kota baru: Ribuan lubang tambang terbengkalai di Kaltim, 'cucu saya tewas di sana, saya harus tuntut siapa?," 2019. [Online]. Available: https://www.bbc.com/indonesia/indonesia-50184425.

[29] H. Dahnur, "Walhi: 19 Orang Tewas Dalam Kecelakaan Tambang Timah di Babel," 2019. [Online]. Available: https://regional.kompas.com/read/2019/08/03/12335231/walhi-19-orangtewas-dalam-kecelakaan-tambang-timah-di-babel.

[30] D. P. Rahayu, "Budaya Hukum Penambang Timah Inkonvensional (TI) Terhadap Mekanisme Perizinan Berdasar Perda Pengelolaan Pertambangan Umum Di Propinsi Kepulauan Bangka Belitung," Masal. Huk., vol. 41, no. 4, pp. 493-504, 2012.

[31] B. Pos, "Nekat Menambang Batu Timah, Dua Penambang Tewas di Tambang Bukit Panjang Desa Mayang," 2016. [Online]. Available: https://bangka.tribunnews.com/2019/07/31/nekatmenambang-batu-timah-dua-penambang-tewas-di-tambang-bukit-panjang-desa-mayangBangka Pos. (2019). Nekat Menambang Batu Timah, Dua Penambang Tewas di Tambang Bukit Panjang Desa Mayang. Retrieved from https://bangka.tribunnews.com/2019/07/31/nekatmenambang-batu-timah-dua-penambang-tewas-di-tambang-bukit-panjang-desa-mayang.

[32] T. Kaltim, "Nyaris Hilang Akibat Tambang, Ini Upaya yang Dilakukan Pemda agar Desa Mulawarman Tak Dihapuskan," 2018. [Online]. Available: https://kaltim.tribunnews.com/2018/01/29/nyaris-hilang-akibat-tambang-ini-upaya-yangdilakukan-pemda-agar-desa-mulawarman-tak-dihapuskan. 